\title{
ДОСЛІДЖЕННЯ ВПЛИВУ КОЛОЇДНИХ ПОВЕРХНЕВО- АКТИВНИХ РЕЧОВИН НА СТРУКТУРОУТВОРЕННЯ ДРІБНОЗЕРНИСТИХ БЕТОНІВ
}

\section{INVESTIGATION OF THE EFFECT OF COLLOID SURFACE- ACTIVE SUBSTANCES ON THE STRUCTURE OF BUILDING OF FINE-GRAINED CONCRETES}

\author{
Шишкіна О.О., к.т.н., доц. (Криворізький національний \\ університет)
}

Shishkina O.O., Ph.D. in Engineering, Associate Professor, (Kryvyi Rih National University)

Досліджено вплив колоїдних поверхнево-активних речовин на структуроутворення дрібнозернистих бетонів за допомогою визначення кількості хімічно зв'язаної води, структурної міцності цементного тіста та зміни міцності бетону в часі.

Concrete is one of the most commonly used building materials, the volume of its production is quite significant. Taking into account that the monolithic method of building of buildings and structures is becoming more widespread, the demand for high-strength and especially highstrength concrete as well as concrete that can withstand rigid operating conditions is constantly increasing. In the manufacture of building structures and products, including monolithic, which operate under aggressive environments, as well as in the repair of reinforced concrete structures, the most effective use of fine-grained concrete. In order to increase the efficiency of concrete use, a great deal of attention is paid to the study of methods for improving the properties of concrete, in particular, for increasing durability, accelerating the periods of hardening, and adjusting the rheological properties of a concrete mixture. Such concrete should have certain specific properties, in particular high rate of formation of the structure, and, as a consequence, strength to shorten the construction time. The methods currently used to accelerate the hardening of concrete have significant drawbacks. In particular, this applies to the use of surfactants. The purpose of this work is to determine 
the influence of aliphatic hydrophobic colloidal surfactant on the processes of hydration of cement when obtained fine-grained concrete. The results of these experiments showed that the introduction of "portland cement-water" into the disperse system of an aliphatic hydrophobic colloidal surface-active substance leads to an increase in the amount of bound water in the system. Also, a change in the structural strength of the cement paste with the addition of an aliphatic hydrophobic colloidal surfactant was investigated. As a result, it was found that the use of such a surfactant in the first hours reduces, and later increases the structural strength of the cement dough. In addition, the change in the strength of concrete containing an aliphatic hydrophobic colloidal surfactant in time was investigated. It has been determined that the use of this surfactant is more effective than the use of other types of surfactants.

Ключові слова: дрібнозернистий бетон, колоїдні поверхневоактивні речовини, асоціати, гідратація, цемент.

Keywords: fine-grained concretes, colloid surface-active substances, associates, hydration, cement.

Сучасний світ характеризується бурхливим розвитком практично усіх галузей господарства, в тому числі будівництва. Так як бетон $\epsilon$ одним 3 найчастіше застосовуваних будівельних матеріалів, об'єми його виробництва досить значні. Для підвищення ефективності його використання приділяється велика увага дослідженню методів покращення властивостей бетонів, зокрема підвищення міцності, прискорення термінів тужавіння, регулювання реологічних властивостей бетонної суміші.

3 урахуванням того, що монолітний спосіб зведення будівель $i$ споруд набуває все більшого розповсюдження, повсякчас зростає потреба у високо- та особливо високоміцних бетонах, а також бетонах, які здатні витримувати жорсткі умови експлуатації. Окрім цього, на сьогоднішній день в усьому світі особлива увага приділяється вирішенню питання економії енергетичних та матеріальних ресурсів.

У сфері виробництва бетонів новітні технології дали змогу створити високоякісні, високотехнологічні, високофункціональні бетони (High Performance Concrete, НРС). Під цим терміном об'єднані багатокомпонентні бетони 3 високими експлуатаційними 
властивостями, міцністю, довговічністю, адсорбційною здатністю, низьким коефіцієнтом дифузії й стиранністю, надійними захисними властивостями стосовно сталевої арматури, високою хімічною стійкістю, бактерицидністю й стабільністю об'єму. Для скорочення термінів будівництва, що особливо актуально при монолітному будівництві, передові країни активно розвивають нові покоління бетонів у тому числі із прискореними строками твердіння й набору міцності.

При виготовленні будівельних конструкцій та виробів в тому числі монолітних, які працюють в умовах дії агресивних середовищ, a також при ремонті залізобетонних конструкцій, найбільш ефективно застосовувати дрібнозернисті бетони. Такі бетони повинні володіти певними специфічними властивостями, зокрема високою швидкістю формування структури, i, як наслідок, міцності для скорочення термінів проведення будівництва. Зазвичай, для того щоб прискорити твердіння бетону при виробництві конструкцій використовують підвищення питомої поверхні цементу; вплив підвищеної температури твердіння бетону, як при нормальному атмосферному, так і при підвищеному тиску; введення добавок, що прискорюють твердіння. Однак кожний із означених методів має свої недоліки. Наприклад, підвищення питомої поверхні цементу доцільно здійснювати до певної величини, адже іiі перевищення призводить до зворотної агрегації часток цементу. Крім того, цей метод може призвести до значного збільшення витрат на виготовлення бетону. В свою чергу теплова обробка бетонів також має свої обмеження. Необхідно пам'ятати, що згідно нормативних документів, температуру ізотермічного прогріву для одержання високоякісних (у тому числі морозостійких) бетонів треба зменшувати до 333К. Одним 3 поширених методів прискорення формування міцності бетону $\epsilon$ застосування добавок-прискорювачів твердіння. Проте вони володіють таким значним недоліком, як втручання в хімічні процеси твердіння в'яжучих речовин, що призводить до зміни спрямованості цих процесів та утворювання нових «нестандартних» мінералів. Визначене академіком Ребіндером явище підвищення швидкості твердіння бетону при введенні до його складу незначної кількості гідрофільних поверхнево-активних речовин відкриває новий напрям в управлінні процесами структуроутворення бетону. 


\section{Аналіз останніх досліджень}

Молекули поверхнево-активних речовин (ПАР) мають яскраво виражену дифільність, тобто містять як гідрофобні, так і гідрофільні групи. Зазвичай вони мають будову $\mathrm{RX}$, де $\mathrm{R}$ - вуглеводневий ланцюжок $з$ числом атомів вуглецю від 8 до 18, алкілароматичний радикал або гідрофобний залишок іншої будови, а X - гідрофільна група. Залежно від природи групи $\mathrm{X}$, ПАР можна розділити на неіонні, аніонні й катіонні.

3 точки зору закономірностей впливу розчинів ПАР на швидкість гідратації в'яжучих речовин представляє інтерес така властивість ПАР як утворення міцел. При низьких концентраціях ПАР утворюють істинні розчини, але по досягненню їх певної концентрації, відбувається агрегація молекул ПАР з формуванням міцел. Мінімальне значення концентрації, при якій починається формування міцел, називають критичною концентрацією міцелоутворення - ККМ.

Швидкість хімічних реакцій, що протікають в розчинах, залежить від багатьох чинників. Одним 3 них $\epsilon$ присутність в розчині ПАР i ïx агрегатів. Явище зміни швидкості реакцій в присутності міцел ПАР часто називають міцелярним каталізом. Погляди більшості дослідників в даний час сходяться на тому, що поверхневі явища пов'язані 3 неасоційованими іонами або молекулами і що, отже, міцели не беруть участь в утворенні поверхневих або міжфазних адсорбційних плівок [1].

Серед факторів, які забезпечують зміну швидкості реакції в присутності міцел ПАР, можна виділити:концентрування реагентів всередині або на поверхні міцел 3 їх специфічною орієнтацією (ефект концентрування) та зв'язування частинок, що реагують, міцелярною псевдофазою зі зміною властивостей їх локального мікрооточення (ефект середовища).

До специфічних особливостей розчинів ПАР відносять їх здатність розчиняти всередині міцел малорозчинні у даному середовищі речовини. При цьому утворюються термодинамічно стійкі ізотропні розчини. Саме це є причиною різкого збільшення поглинання міцелами i, як наслідок, розчинення деяких речовин при досягненні ККМ в розчині ПАР (явище солюбілізаціі). Подальше збільшення концентрації ПАР викликає збільшення розчинності пропорційно концентрації ПАР, що пов'язано, в основному, 3 ростом загального числа міцел в одиниці об'єму. 
Здатність міцелярних систем ПАР солюбілізувати різні речовини $є$ їх найважливішою властивістю [2,3]. Солюбілізація призводить до зростання розчинності з'єднань за рахунок їх локалізації в мікрофази супрамолекулярної системи. При цьому істотно змінюються властивості солюбілізату: його гідратація, жорсткість і конформація молекул, а внаслідок цього - його фізикохімічні характеристики. Змінюються комплексоутворюючі, протолітичні, таутомерні, окислювально-відновні властивості, розподіл зарядів в молекулі. Якщо солюбілізовані речовини здатні брати участь в хімічних взаємодіях, то їх розподіл між фазами може визначати швидкість і механізм хімічних реакцій.

Фактично, утворення міцел відбувається у вузькій області концентрацій ПАР поблизу ККМ і супроводжується різкою зміною ряду властивостей розчину (світлорозсіювання, в'язкість, електропровідність, поверхневий натяг, розчинна здатність щодо деяких речовин і ін.), що використовують для визначення ККМ.

ПАР, що утворюють міцели відносяться до гідрофобних колоїдних і мають або аліфатичну або ароматичну структуру вуглецевих радикалів. При концентрації нижче ККМ колоїдна ПАР повністю дисоціює і існує у вигляді іонів. Такі ПАР називають іонними (катіонними i аніонними), а також «колоїдними електролітами». Внаслідок гідрофобної взаємодії навколо довгого вуглеводневого радикала аліфатичної ПАР відбувається ущільнення ажурної структури води і утворюється їі «льодоподібна» область [4,5] (рис. 1).

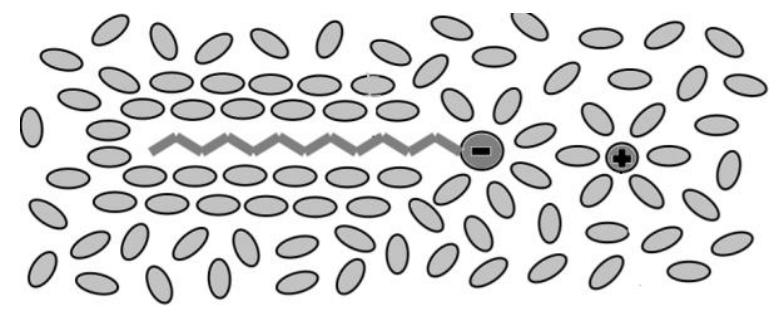

Рис. 1. Структура води навколо молекули колоїдної ПАР

Дослідження об'ємних властивостей розбавлених розчинів гідрофобних аліфатичних ПАР в цілому підтверджують, що відбувається прискорена гідратація мінералів цементу та підвищена 
пептизація його часток, особливо в разі іонних ПАР, які дисоціюють на іони.

\section{Постановка мети і задач досліджень}

Метою даної роботи є визначення впливу аліфатичної гідрофобної колоїдної поверхнево-активної речовини на процеси гідратації цементу при отримані дрібнозернистих бетонів.

Для досягнення поставленої мети необхідно вирішити такі задачі: дослідити вплив аліфатичної гідрофобної колоїдної поверхнево-активної речовини на гідратацію цементу через визначення кількості зв'язаної води, структурної міцності цементного тіста та зміну механічної міцності бетону в часі.

Методика досліджень.

Дослідження проводили згідно із стандартними методиками. Для виготовлення бетону використовували портландцемент M400 ПАТ «Хайдельберг цемент Кривий Ріг» (Україна), дрібний заповнювач - відходи збагачення залізних руд Новокриворізького гірничо-збагачувального комплексу ПАТ «Арселор Мітал Кривий Ріг» (Україна), що мають максимальний розмір частинок 0,63 мм. У якості аліфатичної гідрофобної ПАР (МПАР) - олеат натрію (Simagchem Corp., Китай).

Структурна міцність цементного тіста визначалася за методикою запропонованою Стефановим Б.В. [6] Метод визначення ступеня гідратації за кількістю зв'язаної води обраний у зв'язку 3 тим, що він дозволяе не тільки простежити ступінь гідратації кожного мінералу портландцементу, а й фіксувати зміну кількості хімічно зв'язаної води в залежності від вмісту МПАР. Механічна міцність бетону визначалася стандартними методами.

Результати досліджень.

В першій групі дослідів визначалася кількість зв'язаної води в системах «портландцемент - вода» та «портландцемент - вода МПАР». Кількість хімічно зв'язаної води цементом, що застосовували у дослідах, при твердінні приведено в табл. 1.

Результати проведених експериментів показали, що введення в дисперсну систему «портландцемент - вода» МПАР в умовах експерименту призводить до збільшення кількості зв'язаної води. 
Таблиця 1

Кількість хімічно зв'язаної води в продуктах гідратації дисперсної системи «портландцемент - вода»

\begin{tabular}{|c|c|c|}
\hline \multirow{2}{*}{$\begin{array}{c}\text { Завод-виробник } \\
\text { цементу }\end{array}$} & \multicolumn{2}{|c|}{ Кількість хімічно зв’язаної води, \% } \\
\cline { 2 - 3 } & без МПАР & з МПАР \\
\hline $\begin{array}{c}\text { ПАТ «Хайдельберг } \\
\text { цемент Кривий Ріг» }\end{array}$ & 16,09 & 17,95 \\
\hline
\end{tabular}

Отримані результати експериментів доводять, що введення МПАР в систему «портландцемент-вода» призводить до прискорення гідратації цементу, що й підтверджується збільшенням кількості хімічно зв'язаної води.

В наступній групі експериментів досліджувалася структурна міцність дисперсної системи «портландцемент - МПАР - вода» в залежності від часу її структуроутворення.

В умовах проведення експерименту введення до складу дисперсної системи «портландцемент - вода» МПАР призводить до зменшення величини структурної міцності отриманого матеріалу (рис. 2) в перші години. Але з часом структурна міцність дисперсної системи «портландцемент - вода - МПАР» різко збільшується i перевищує структурну міцність дисперсної системи «портландцемент - вода». Це явище також підтверджує прискорення гідратації мінералів портландцементу.

В подальшому була досліджена зміна міцності бетону в часі (рис.3).

3 результатів експериментів видно, що застосування МПАР більш ефективно, ніж застосування гідрофільної ПАР - ССБ, а також гідрофобної ароматичної ПАР - милонафту (рис. 3). Це обумовлено тим, що введення МПАР забезпечує найбільшу швидкість формування міцності бетону та іiі величину.

Отримані в ході досліджень результати можна пояснити наступним чином.

Механізм дії ПАР в процесах твердіння в'яжучих в розглядався П. О. Ребіндером. У зв'язку з відкритим їм ефектом зниження міцності твердих тіл, в ранніх роботах він пояснив вплив малих додавань цих речовин на властивості цементного каменю як наслідок подрібнення кристалічної структури (модифікації) в результаті розклинюючої дії тонких адсорбційних шарів модифікатора на поверхні цементних зерен $[7,8]$. 
Структурна міщність, кПа

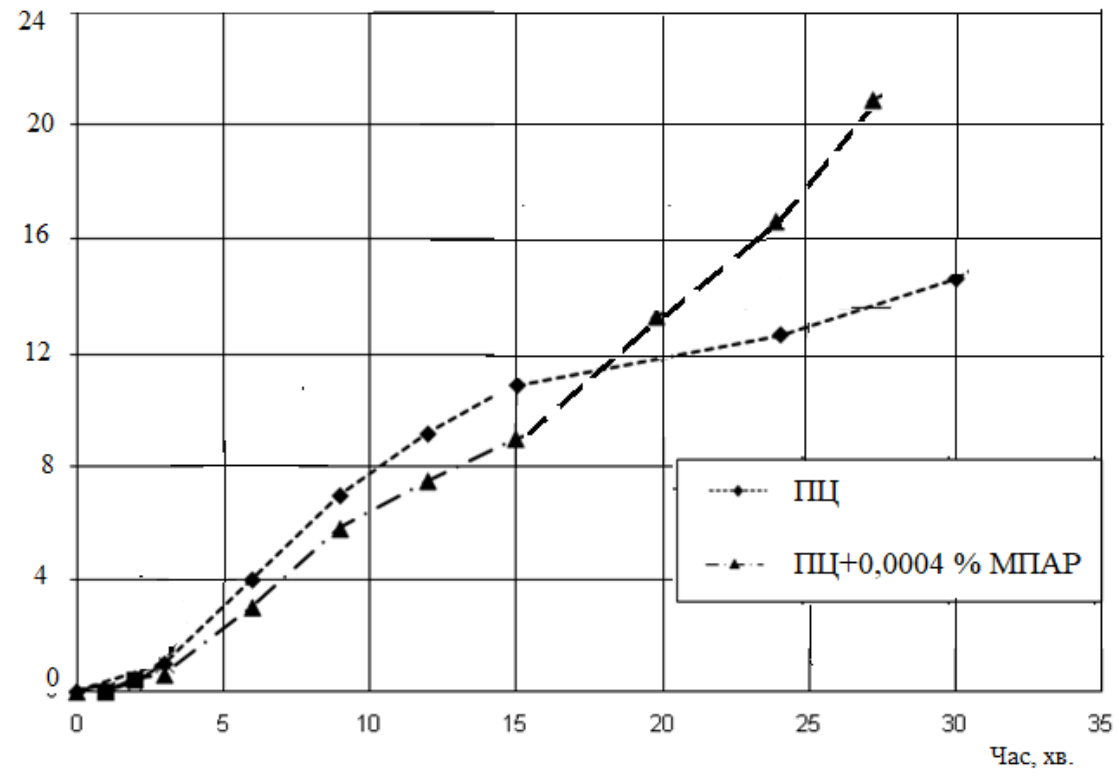

Рис. 2. Структурна міцність дисперсної системи «портландцемент - вода - МПАР»

(ПЦ - портландцемент)

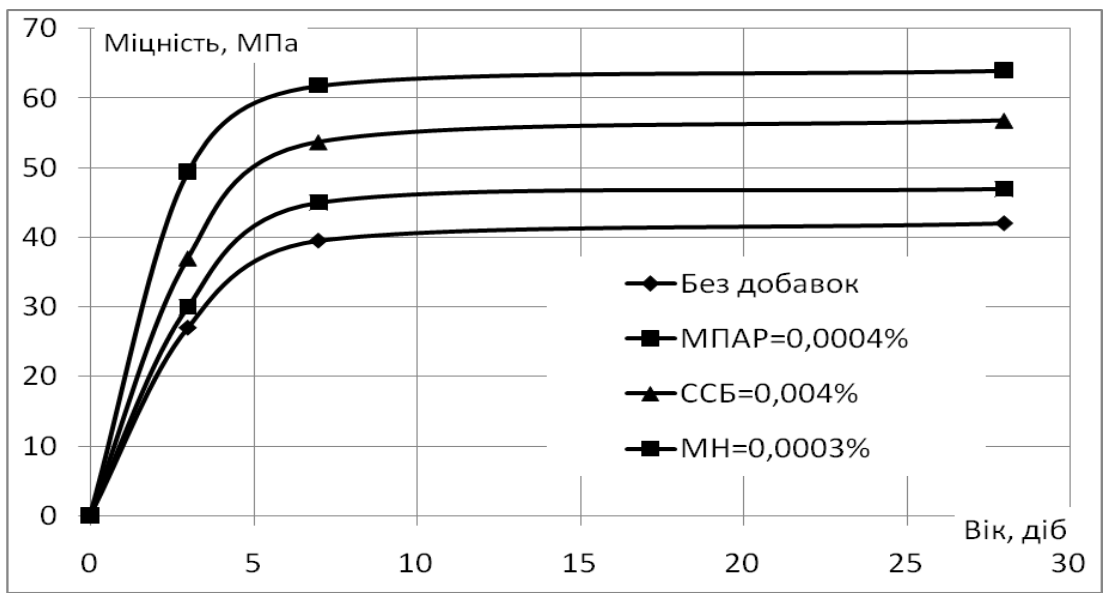

Рис. 3. Вплив виду поверхнево-активної речовини на швидкість формування міцності 
При цьому хімічна природа добавок визначає будову адсорбційних шарів і відповідно до орієнтації частин молекули ПАР - гідрофілізацію або гідрофобізацію поверхні [7,8].

Подальші дослідження підтвердили модифікуючу дію ПАР, особливо гідрофільного характеру, і значне збільшення дисперсності твердої фази в їх присутності [7-10].

У роботах по вивченню механізму структуроутворення в цементних суспензіях в присутності гідрофільних ПАР (переважно ССБ) на процеси розчинення і виділення нових фаз в розбавлених суспензіях гіпсу і силікатів кальцію [4] відзначається, що поряд 3 адсорбцією добавки на поверхні частинок в'яжучого значну роль відіграє і стабілізація зародків гідратної фази. 3 цих позицій можна пояснити цілий ряд явищ, які спостерігаються при введенні ПАР в цементну суспензію, зокрема, знаходить пояснення і підвищена концентрація розчинних компонентів в рідкій фазі цементної суспензії в присутності ССБ [10].

Відмінності в реакційній здатності ПАР різної будови, зумовлені активністю (ступенем дисоціації) полярних груп в залежності від молекулярної маси, хімічної природи і будови вуглеводневого радикала, що визначає взаємне розташування i відстань між активними групами [4,5].

Слід також відзначити певний вплив вуглеводневої частини макромолекули ПАР. Ї̈̈ наявність в системі змінює структуру води в безпосередній близькості від поверхні в бік зменшення розчинності новоутворень і відповідно впливати на їх морфологію [4,5].

Явища адсорбції ПАР на поверхні безводного в'яжучого або гідратних фаз лежать в основі дії не тільки гідрофільних, але i гідрофобних добавок.

Гідрофобні ПАР мають різну будову, яка відбивається у їх впливі на процеси структуроутворення в системі «портландцемент вода». Найбільш поширеними є гідрофобні ПАР солі аліфатичних ненасичених карбонових кислот (зокрема олеат натрію) та солі ароматичних карбонових кислот (зокрема милонафт) [10].

Грунтуючись на структурі колоїдної поверхнево-активної речовини, яка запропонована П.О. Ребіндером [4] та розвинута М.О. Мчедловим-Петросяном [5] (рис. 1), іiі адсорбцію на поверхні частинок цементу можна уявити за схемою, наведеною на рис. 4. 


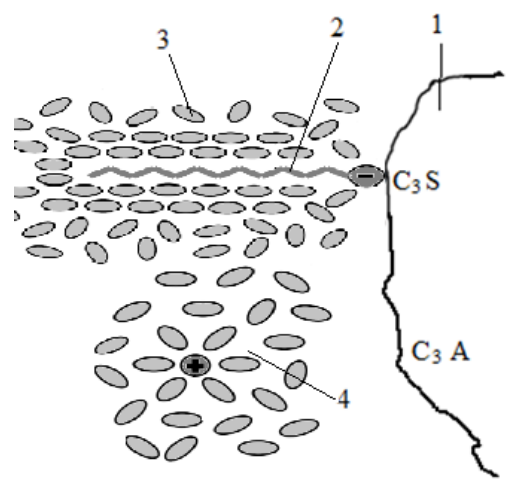

Рис. 4. Схема адсорбції молекули аліфатичної колоїдної ПАР на частинці цементу: 1 - частинка цементу; 2 - вуглеводневий радикал ПАР; 3 - молекули структурованої води; 4 - Na-кластер

Тобто, при концентраціях гідрофобної колоїдної ПАР менше

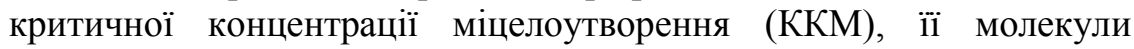
вибірково адсорбуються на $\mathrm{C}_{3} \mathrm{~S}$ цементу, залишаючи контакт трикальцієвого алюмінату з водою, тобто не перешкоджають його гідратації.

В той же час встановлено [11,12] існування задовго до досягнення ККМ початку колективної міжмолекулярної взаємодії ПАР - критичної концентрації субміцелоутворення (ККСМ). При цьому досягається максимальна структуризація води (зміцнення водневих зв'язків навколо вуглеводневого радикалу, зневоднення гідрофільної групи). Причому ККСМ, а не ККМ відповідає істинній розчинності ПАР.

При комплексному дослідженні асоціації ПАР встановлено, що до ККСМ вони утворюють іонні пари тільки 3 проти знаковими іонами [11,12]. По мірі збільшення концентрації наступає колективна асоціація ПАР (асоціація одно знаковими органічними іонами).

Тобто, при ККСМ утворюються асоціати молекул (дімери), які не адсорбуються на поверхні силікатів цементних часток, а руйнують їх, за рахунок утворення солей кальцію. Це призводить до збільшення пептизації цементу, його розчинення, що і обумовлює прискорення гідратації цементу, що забезпечує прискорення формування структури цементного каменю та, як наслідок, прискорення формування міцності цементу. 
Окрім цього, гідрофобні ПАР, які мають аліфатичну структуру вуглеводневого радикалу, забезпечують контакт структурованої води $з$ поверхнею частинок цементу. Тобто достатньо наочно видна певна тотожність схем адсорбції гідрофільних ПАР при малих їх концентраціях та гідрофобних ПАР, які мають аліфатичну структуру вуглеводневого радикалу, при концентраціях менше ККМ. В обох випадках навколо молекул ПАР концентрується структурована вода, яка контактує з поверхнею часток цементу.

У той же час, гідрофобні ПАР, які мають на відмінну від аліфатичної, ароматичну структуру вуглеводневого радикалу (наприклад милонафт) не можуть забезпечити контакт структурованої води із частинками цементу навіть при незначній кількості означених ПАР.

Вплив же структурованої води на процеси гідратації мінералів цементу достатньо вивчений. Так структурована вода забезпечує високий ступінь і швидкість гідратації сухої речовини (швидкість розчинення неорганічних солей збільшується в десятки разів) 3 більш глибоким і рівномірним заглибленням частинок в'яжучого в структуру частинок наповнювача. Тобто, при малих концентраціях, гідрофобні аліфатичні колоїдні ПАР, які мають форму вуглеводневого радикалу близьку до лінійної окрім забезпечення руйнації часток цементу виконують роль «транспортерів» структурованої води до часток цементу, що й призводить прискорення його гідратації, а отже і формування міцності бетону.

\section{Висновки}

На основі виконаних досліджень встановлено:

1. Аліфатичні гідрофобні колоїдні поверхнево-активні речовини при здійснюють вплив на процеси гідратації цементу.

2. Доведено, що введення аліфатичної гідрофобної колоїдної поверхнево-активної речовини до складу бетону у кількості менше критичної концентрації субміцелоутворення збільшує кількість хімічно зв'язаної води на $12 \%$, величину структурної міцності цементного тіста на $62 \%$, що сприяє збільшенню міцності бетону на 79\% у ранньому віці і на $50 \%$ у віці 28 діб.

3. Означені результати пояснюються взаємодією дімерів аліфатичної гідрофобної колоїдної поверхнево-активної речовини із силікатами портландцементу, що сприяє пептизації його частинок. Крім того дімери аліфатичної гідрофобної колоїдної поверхнево- 
активної речовини $є$ «транспортерами» структурованої води до поверхні частинок цементу, що сприяє прискоренню реакцій гідратації силікатів не впливаючи на швидкість гідратації алюмінатів.

\section{Список використаних джерел}

1. Marusin S.L. Shotwell L.B. Alkali-silica reaction in concrete caused by densified silica fume lumps: a case study. Cem., Concr. \& Aggregates. 2000. Vol. 22, No 2. 90-94. 2. Ланге, К. Р. Поверхностно-активные вещества. Синтез, свойства, анализ, применение. Санкт-Петербург, 2005. 240. 3. Савин, С. Б. Чернова Р. К., Штыков С. Н. Поверхностно-активные вещества. Москва: 1991. 250. 4. Ребиндер П.А. Избранные труды. Поверхностные явления в дисперсных системах. Коллоидная химия. Москва, 1978. 366. 5. Мчедлов-Петросян Н.О., Лебедь А.В., Лебедь В.Н. Коллоидные поверхностно-актиные вещества. - Х. 72. 6. Стефанов Б.В., Русанова Н.Г. Технология бетонных и железобетонных изделий. 1982. 406 с. 7. Ребиндер П. А., Венстрем Е. К. Стабилизация гидрофобных и гидрофильных суспензий ПАВ. Журн. физ. химии. 1930. № 1. с. 2.8. Ребиндер П. А,, Ребиндер К. П. Пассивирующие (отрицательнокаталитические) действия адсорбционных слоев поверхностно-активных веществ. Журн. физ. химии, 1930. т. 1. вып. 2. с. 175-188. 9. Ребиндер П. А. Физико-химия моющего действия. 1935. 162 с. 10. Глекель Ф.П., Копп Р.3., Ахмедов К.С. Регулирование гидратационного структурообразования поверхностно-активными веществами. 1986. 224. 11. Миргород Ю.А., Самойлов О.Я. и др. Журн. физ. химии. 1975. Т.41. №6. С.1442 -1446. 12. Mirgorod Yu. A., Kurdyukov A.V., Postnikov E.V. Russ. J. Phys. Chem. 2005. V.79. №8. P.1203 - 1208 . 